\title{
LUDSKÉ ZDROJE - REGIONÁLNE DISPARITY V KONTEXTE POLITIKY SÚDRŽNOSTI EÚ 2007 - 2013 NA SLOVENSKU
}

\author{
Eva Rajěáková, Angelika Švecová* \\ * Univerzita Komenského v Bratislave, Prírodovedecká fakulta, Katedra regionálnej geografie, ochrany \\ a plánovania krajiny, Ilkovičova 6,84215 Bratislava, rajcakova@fns.uniba.sk, asvecova@fns.uniba.sk
}

\begin{abstract}
Human resources: regional disparities in context of the EU Cohesion policy 2007 - 2013 in Slovakia

Human resources are a significant factor in the development of the region. Spatial differentiation of demographic developments, structural phenomena and social standards of the population crucially determine regional differences in human resources. The EU structural Funds are one of the important tools for the elimination of regional disparities in this field. The aim of this paper is to evaluate the regional disparities in human resources by selected indicators of demographic and social fields at the regional level in Slovakia in the context of the implementation of the Cohesion policy EU 2007 - 2013 instruments under the strategic priority 3 - Human resource and Operational Programme for Employment and Social Inclusion and the Operational Programme for Education.
\end{abstract}

Keywords: human resources, regional disparities, Cohesion policy $2007-2013$, region, Slovak Republic

\section{ÚVOD}

Ludské zdroje predstavujú významný faktor rozvoja regiónu. Demografický vývoj a štrukturálne znaky obyvatel'stva sú primárne charakteristiky, ktoré spolurozhodujú o početnosti a kvalite ludských zdrojov. Sociálna úroveň obyvatel'stva je priamym dôsledkom ekonomického statusu a situácie na trhu práce a ovplyvňuje ju celý rad d’alších faktorov. Priestorová diferenciácia týchto procesov a javov rozhodujúcou mierou determinuje regionálne rozdiely v oblasti l'udských zdrojov. V posledných rokoch sú regionálne rozdiely ovplyvnené aj implementáciou národných a dopytovo orientovaných projektov, ktoré prispeli k naplneniu ciel'ov strategickej priority 3. Ludské zdroje Národného strategického referenčného rámca 2007-2013 (NSRR 2007 - 2013).

Ciel’om príspevku je poukázat' na zmeny vo vývoji regionálnych disparít v oblasti l'udských zdrojov podla krajov Slovenska a odpovedat' na otázku, či vývoj a zmeny regionálnych disparít $\mathrm{v}$ oblasti l'udských zdrojov boli ovplyvnené implementáciou finančných prostriedkov (Európskeho sociálneho fondu) politiky súdržnosti v rokoch $2007-2013$.

\section{REGIONÁLNE DISPARITY - TEORETICKÉ VÝCHODISKÁ}

Regionálne rozdiely (disparity) sú frekventovaným pojmom a ich riešenie predmetom vedeckých a odborných štúdií z viacerých oblastí (geografie, sociológie, ekonómie, regionálneho rozvoja a politiky a i.). Vo všeobecnosti sa disparity chápu ako „,nerovnomernosti, rozdiely, heterogenity či diferencie“ (Viturka 2010, p. 131). $\mathrm{K}$ chápaniu pojmu možno pristupovat' z viacerých hl'adísk. Vo vzt’ahu k priestorovej dimenzii je pojem definovaný ako „štruktúrovaný jav, tvorený systémom prv- 
kov, väzieb a vzt'ahov, ktorý sa prejavuje kumuláciou (ne-)priaznivých javov ovplyvňujúcich rozvoj určitej oblasti v danom priestore“ (Chabičovská et al. 2009, p. 13). V aplikačnej rovine autori rozlišujú javy s pozitívnym alebo negatívnym vplyvom na rozvoj regiónu s diferencovanými dôsledkami na prehlbovanie alebo zmierňovanie regionálnych nerovností. Podl'a Kutscherauera (2007, p. 7) pojem vyjadruje ,rozdielnosti, nerovnosti znakov, javov alebo procesov, ktorých identifikácia a porovnanie má racionálny zmysel (poznávací, ekonomický, sociologický, psychologický a i.)“. Autor zdôrazňuje význam priestorovej a časovej dimenzie a potrebu poznania miery zaostávania vo vzt’ahu k rozvoju. Vývoj geografických a sociálnych nerovností je prejavom hierarchickej organizácie spoločnosti a dôležitým predmetom štúdia spoločnosti, nerovnomernosti môžu byt' zdrojom sociálneho a regionálneho napätia a nestability spoločnosti, na druhej strane sú vnímané ako podnety d'alšieho vývoja (Hampl 2005). Rozvojové disparity vznikajú vývojovou diferenciáciou spoločenských systémov, pričom účinnost' ich regulácie je determinovaná mierou rešpektovania zákonitostí sociálno-ekonomickej a sociálno-geografickej organizácie spoločnosti, vhodne zvolenou regionálnou politikou a použitými nástrojmi (Viturka 2010). V súvislosti s regionálnou štruktúrou a diferenciáciou viacerí autori (Korec 2005, Michaeli et al. 2010, Rajčáková a Švecová 2011 a iní) prezentujú názor, že demokratizačný proces po roku 1989 výrazne ovplyvnil sociálno-priestorovú situáciu na Slovensku. Prišlo ku koncentrácii sociálnych a ekonomických problémov, polarizácii územia, pomerne výraznej priestorovej diferenciácii regiónov a prehlbovaniu regionálnych disparít. Rozdielne prírodno-geografické a sociálno-ekonomické podmienky a potenciál regiónov spolu s historickými špecifikami sa odrážajú v regionálnej štruktúre Slovenska (Buček et al. 2010). Regióny disponovali rozdielnym ,štartovacím“ kapitálom, čo sa odráža v ich d’alšom rozvoji. V tejto súvislosti Gajdoš $(2005$, p. 26) považuje regionálne disparity „za produkt pôsobenia viacerých faktorov, pričom ich vel'kost' závisí od rozvojového potenciálu (disponibilít) a pozície, z ktorej regióny vstupovali do transformačného procesu."

Regionálne disparity odrážajú mieru súdržnosti európskych regiónov v rámci spoločnej a konkurencieschopnej európskej ekonomiky, z čoho je zrejmý úzky vzt'ah medzi ekonomickou výkonnost'ou a konkurencieschopnost'ou regiónov, cielenou a vhodne zvolenou podpornou politikou v závislosti od hierarchickej úrovne regiónov. Dôsledné uplatňovanie nástrojov politiky súdržnosti môže výrazne prispiet' k vyrovnávaniu regionálnych rozdielov a zabezpečeniu ekonomickej a sociálnej kohézie (Dubois 2007, Molle 2007, Wokoun et al. 2008, Hudec et al. 2009, Buček et al. 2010, Viturka 2010, Blažek a Uhlír 2011 a iní).

Hodnotenie regionálnych disparít v kontexte regionálnej politiky EÚ v jednotlivých programových obdobiach je prezentované v prácach viacerých zahraničných (Bachtler a Wren 2006, Bachtler a McMaster 2008, Cace et al. 2009, Dvorak 2010, Mohl a Hegant 2010 a iní) a domácich (Korec a Ondoš 2008, Matlovič a Matlovičová 2011, Rajčáková a Švecová 2011, Matlovičová et al. 2014 a iní) autorov, ktorí na rôznej úrovni komplexnosti hodnotia a analyzujú regionálne rozdiely a možnosti ich riešenia s využitím nástrojov regionálnej politiky EU.

\section{METÓDY A POUŽITÉ DÁTA}

Regionálne disparity v oblasti l'udských zdrojov sú hodnotené v kontexte využívania Európskeho sociálneho fondu (ESF), ktorého prostriedky boli v procese im- 
plementácie operačných programov Zamestnanost' a sociálna inklúzia (OP ZaSI) a Vzdelávanie (OP V) alokované na národné a dopytovo orientované projekty v oprávnených regiónoch NUTS 3 (krajoch) Slovenska.

V súlade s kontextovými ukazovatel'mi strategickej priority 3. L'udské zdroje NSRR 2007 - 2013 boli na hodnotenie regionálnych disparít použité demografické charakteristiky (migračný a celkový prírastok (resp. úbytok) obyvatel'stva, indexy starnutia a vzdelanostnej úrovne obyvatel'stva), ukazovatele sociálnej úrovne (miery evidovanej a dlhodobej nezamestnanosti, miera rizika chudoby a počet poberatel'ov dávok v hmotnej núdzi na 1000 obyvatel'ov). Vzhl'adom na to, že podporné prostriedky boli alokované aj na premenu tradičnej školy na modernú v zmysle skvalitnenia obsahu vzdelávania v súlade s potrebami trhu práce, pri hodnotení regionálnych disparít boli zohl'adnené aj údaje o počte účastníkov celoživotného vzdelávania na 100 obyvatel'ov vo veku 25 - 64 rokov a miera nezamestnanosti absolventov stredných škôl.

Použité boli údaje zo zdrojov Štatistického úradu SR (ŠÚ SR), Ústredia práce sociálnych vecí a rodiny (ÚPSVaR), Ministerstva školstva, vedy, výskumu a športu SR (MŠVVŠ SR) a Centra vedecko-technických informácií SR (CVTI SR) $\mathrm{k}$ začiatku programového obdobia ( $\mathrm{k} 31.12 .2007)$ a ku koncu reálneho ukončenia implementácie projektov ( $\mathrm{k} 31.12$. 2015). Na hodnotenie bola použitá metóda dynamickej medziregionálnej komparácie. Pozícia krajov v regionálnej štruktúre Slovenska je podložená multikriteriálnym rozhodovaním s použitím bodovej metódy. Základom analýzy je matica $\mathrm{Z}$, kde riadky matice $\mathrm{Z}$ zodpovedajú jednotlivým územným jednotkám (krajom) a stĺpce hodnotiacim ukazovatel'om. Pre možnost' porovnania údajov sú všetky ukazovatele transformované podl'a vzt'ahu

$$
R_{i j}=\frac{\max z_{i j}}{z_{i j}},
$$

kde max $z_{i j}$ je maximálna hodnota prvku $\mathrm{v}$ danom stĺpci, $z_{i j}$ je pôvodný prvok v danom stlpci. Prvky boli normalizované podl'a vzt’ahu

$$
r_{i j}=\frac{z_{i j}-d_{j}}{h_{i j}-d_{j}},
$$

kde $d_{j}$ je minimálna hodnota prvku v danom stĺpci, $h_{j}$ je maximálna hodnota prvku $\mathrm{v}$ danom stĺpci (hodnoty sú v intervale od 0 do 1). Po maximalizácii, normalizácii a pridelení bodových hodnôt bola určená pozícia regiónov NUTS 3 (krajov) v regionálnej štruktúre Slovenska a regióny mohli dosiahnut' maximálne 1000 bodov. Regionálne disparity boli vyjadrené štandardnými nástrojmi na meranie nerovností (variačné rozpätie, smerodajná odchýlka, Giniho koeficient).

Finančná implementácia vychádzala z údajov Centrálneho koordinačného orgánu (CKO) o stave realizovaných projektov a výdavkov OP ZaSI a OP V k 31. 12. 2015. Výdavky národných projektov OP V boli rovnomerne rozpočítané do krajov, v prípade OP ZaSI bola použitá dezagregačná metóda podl'a počtu obyvatel'ov. Pre dopytovo orientované projekty bola zohl'adnená reálna alokácia podpory podl'a regiónov NUTS 3. Príspevky technickej pomoci operačných programov, určené na aktivity národnej úrovne $\mathrm{s}$ miestom prijímatel'ov $\mathrm{v}$ Bratislave, neboli $\mathrm{v}$ analýze zohl'adnené. 


\section{LUUDSKÉ ZDROJE - REGIONÁLNE DISPARITY NA SLOVENSKU}

Demografickými procesmi, ktoré v posledných rokoch ovplyvňujú počet obyvatel'ov regiónov NUTS 3 sú prirodzený a migračný prírastok (resp. úbytok) obyvatel'stva. Prirodzený prírastok (resp. úbytok) je predovšetkým ovplyvnený ekonomickými faktormi, preferenciou jedno až dvojdetného modelu rodiny a skutočnost’ou, že do fertilného veku sa dostali populačne „silné“ ročníky z 80. rokov. V priestorovej diferenciácii prirodzeného pohybu sa prejavujú regionálne rozdiely, ktoré odrážajú všeobecné trendy a regionálne špecifiká. V krajoch, ktoré z hl'adiska sociálno-ekonomickej úrovne patria k dynamicky a najdynamickejšie sa rozvíjajúcim (Švecová a Rajčáková 2014) je nadpriemerný migračný prírastok (Bratislavský 9,73\%o, Trnavský 2,64 \%o), ostatné kraje dlhodobo zaznamenávajú migračný úbytok obyvatel'stva od $-0,19 \%$ (Košický) do -2,03 \%o (Prešovský). Kraje s prirodzeným a migračným úbytkom vykazujú celkový úbytok obyvatel'stva (Banskobystrický $-3,58 \%$, Nitriansky $-3,51 \%$ a Trenčiansky $-2,20 \%$ ), čo sa v prípade dlhodobého vývoja prejavuje v deprivácii vekovej a vzdelanostnej štruktúry obyvatel'stva. Nadpriemerný prirodzený prírastok spolu miernym migračným úbytkom v Prešovskom a Košickom kraji ovplyvňujú celkový prírastok obyvatel'stva (Prešovský 0,88 \%o a Košický $1,36 \%$ \% približne na úrovni priemeru SR (0,90 \%o). Celkový prírastok obyvatel'stva v Trnavskom (1,82 \%o) a Bratislavskom (12,82 \%o) kraji je dôsledkom nadpriemernej medzi- a vnútroregionálnej migrácie v posledných rokoch. $\mathrm{V}$ súlade $\mathrm{s}$ očakávaným poklesom intenzity migrácie možno očakávat' stabilizáciu až mierny pokles celkového prírastku obyvatel'stva v týchto krajoch (Bleha et al. 2014).

$\mathrm{V}$ kontexte $\mathrm{s}$ vývojom a situáciou na regionálnych trhoch práce, nárokmi na ekonomické zabezpečenie a sociálnu starostlivost' je významnou štrukturálnou charakteristikou veková štruktúra, ktorá poukazuje na starnutie obyvatel'stva. Index starnutia sa zvýšil zo $76 \%$ v roku 2007 na 94,22 \% v roku 2015 s regionálnymi rozdielmi, ktoré sú dôsledkom dlhodobého regionálne diferencovaného demografického správania obyvatel'stva. Najvyššie hodnoty indexu starnutia sú v Trenčianskom $(119,55 \%)$ a Nitrianskom $(118,09 \%)$ a podpriemerné v Prešovskom $(70,12 \%)$ a Košickom $(77,46$ \%) kraji, čo je dôsledkom nadpriemerného prirodzeného prírastku predovšetkým rómskej populácie (Vaňo 2002).

Podl'a indexu vzdelanostnej úrovne a podielu obyvatel'stva s vysokoškolským vzdelaním má dominantnú pozíciu Bratislavský kraj (156,7 tis., 26,20 \% obyv.), kým v ostatných krajoch sa podiel obyvatel'stva s vysokoškolským vzdelaním pohybuje od 11,50 \% (Trnavský) do 13,00 \% (Žilinský). V posledných rokoch sa znižuje podiel obyvatel'stva s nižším stredným vzdelaním a rastie záujem o úplné stredné vzdelanie, ktoré v súlade s potrebami trhu práce rozširuje ponuku o moderné odbory s vysokou uplatnitel'nost'ou absolventov na trhu práce (Herich 2014). Hodnota indexu vzdelanosti vzrástla zo 46,08 v roku 2007 na 57,30 (+11,22 bodov) v roku 2015. Najvýraznejší kvalitatívny posun vzdelanostnej úrovne obyvatel'stva bol v Bratislavskom, Trenčianskom, Košickom a Žilinskom kraji s koncentráciou nielen tradičných, ale aj nových inovatívnych odborov vysokých a stredných škôl, ktoré reflektujú potreby regionálneho hospodárstva. V roku 2015 najvyššiu hodnotu indexu vzdelanostnej úrovne dosiahlo obyvatel'stvo Bratislavského $(82,37)$ a Košického $(56,54)$ kraja, v ostatných krajoch sa index vzdelanostnej úrovne pohybuje od 49,74 (Prešovský) do 55,14 (Trenčiansky). 
Kvalitná vzdelanostná úroveň obyvatel'stva je jedným z predpokladov vyrovnaného charakteru trhu práce, vyššej miery zamestnanosti, príjmov a životnej úrovne obyvatel'stva.

$\mathrm{Na}$ regionálnych trhoch práce sa prejavuje výrazná štrukturálna nerovnováha medzi ponukou a dopytom, ktorá je výsledkom pôsobenia viacerých faktorov globálneho charakteru (vplyv finančnej ekonomickej krízy na regionálne hospodárstvo, nesúlad medzi vzdelanostnou a profesijnou štruktúrou pracovnej sily a nárokmi zamestnávatel'ov, nedostatočné prepojenie vzdelávacieho systému s potrebami trhu práce, slabé siet'ovanie ekonomických subjektov, vstup rozvojového kapitálu a zahraničných investorov, slabá intenzita migrácie za prácou a i.) a regionálnych špecifik (výkonnost' a konkurencieschopnost' regionálneho hospodárstva, adaptabilita pracovnej sily na požiadavky trhu práce a i. - Hanzelová 2015). V miere evidovanej nezamestnanosti sa prejavujú výrazné regionálne disparity. Dynamicky sa rozvíjajúce a konkurencieschopné kraje (Bratislavský, Žilinský, Trnavský a Trenčiansky) poskytujú relatívne dostatočný počet pracovných miest v tradičných odvetviach (priemysel, stavebníctvo a doprava), terciárnom a kvartérnom sektore a v súčasnosti vo viacerých $\mathrm{z}$ nich ponuka vol'ných pracovných miest prevyšuje dopyt. Vývoj miery evidovanej nezamestnanosti má na celoštátnej úrovni kolísavý priebeh, s prudkým nárastom miery evidovanej nezamestnanosti v rokoch 2009 až 2013. Makroekonomická prosperita pokrízového vývoja viedla ku koncu roku 2015 ku zníženiu miery evidovanej nezamestnanosti na 10,63\%, ktorá je však o 2,64 percentuálneho bodu vyššia ako v roku 2007 (7,99 \%) s výraznými regionálnymi rozdielmi a najnižšími hodnotami v Bratislavskom $(5,34 \%)$, Trnavskom $(6,71 \%)$, Trenčianskom $(7,71 \%)$ a Žilinskom $(8,86 \%)$ kraji. Trvalo nadpriemerná miera evidovanej nezamestnanosti v Košickom (14,39 \%), Banskobystrickom $(14,94 \%)$ a Prešovskom (15,50 \%) kraji je ,sprevádzaná“ negatívnymi štrukturálnymi znakmi regionálnych trhov práce.

Dlhodobá nezamestnanost' (12 a viac mesiacov) má na Slovensku v porovnaní s krátko- a strednodobou nezamestnanost’ou rozdielny trend vývoja a nežiaduce ekonomické a sociálne dôsledky (znižovanie príjmov a životnej úrovne obyvatel'stva, nárast počtu sociálne odkázaných osôb, zvyšovanie miery rizika chudoby, sociálna exklúzia a i.). Miera dlhodobej nezamestnanosti je považovaná za „,barometer“ sociálnej situácie v štáte (regióne - Lubyová et al. 2015). Miera dlhodobej nezamestnanosti má nerovnomerný vývoj. Do roku 2008 sa celkový počet dlhodobo nezamestnaných a miera dlhodobej nezamestnanosti $\mathrm{v}$ súlade $\mathrm{s}$ rastúcou ekonomickou prosperitou, tvorbou pracovných miest a legislatívnymi zmenami (zaradenie dlhodobo evidovaných uchádzačov o zamestnanie (UoZ) na verejnoprospešné práce) znižovali. Avšak od roku 2009 prišlo k pomerne výraznému medziročnému nárastu dlhodobo nezamestnaných na národnej a regionálnych úrovniach. Priaznivá trajektória (makro-) ekonomického vývoja v posledných rokoch sa pozitívne, aj ked' s istým časovým oneskorením, prejavuje aj na trhu práce a vo vývoji dlhodobej nezamestnanosti. K 31. 12. 2015 bolo na Slovensku 172,92 tis. a dlhodobo nezamestnaných $(51,71 \%)$, z toho viac ako tri štvrtiny v štyroch krajoch (Prešovský 44,84 tis., Banskobystrický 33,82 tis., Košický 37,17 tis. a Nitriansky 18,95 tis.), ktoré dosahovali aj najvyššiu mieru dlhodobej nezamestnanosti (Prešovský 10,54 \%, Banskobystrický 10,46 \%, Košický 10,07 \% a Nitriansky $5,42 \%$ ), najnižšia miera dlhodobej nezamestnanosti bola v Bratislavskom $(2,09 \%)$ a Trnavskom $(2,76 \%)$ kraji. 
Miera rizika chudoby, vyjadrená ako podiel osôb s ekvivalentným disponibilným príjmom pod $60 \%$ národného mediánu ekvivalentného disponibilného príjmu, sa neustále zvyšuje. Okrem makroekonomického vývoja, diferencovanej výkonnosti regionálnych ekonomík a životnej úrovne obyvatel'stva, reflektuje vzdelanostnú úroveň a adaptabilitu pracovných zdrojov na regionálnych trhoch práce. Hospodárska kríza „umocnila“ koncentrovaný vplyv negatívnych faktorov, ktoré viedli k rastúcej chudobe obyvatel'stva. V rokoch 2007 - 2015 na Slovensku vzrástol počet osôb pod hranicou chudoby približne o 92,82 tis. Osoby pod hranicou chudoby sú koncentrované najmä v Prešovskom (125,94 tis., 19,11 \% SR), Košickom (104,26 tis., 15,81 \% SR) a Banskobystrickom (108,51 tis., 16,46 \% SR) kraji; absolútne najnižší počet osôb pod hranicou chudoby je v Bratislavskom (46,47 tis., 7,05 \% SR) a Trnavskom (45,69 tis., 6,93 \% SR) kraji, ktoré spolu s Trenčianskym krajom $(8,90 \%)$ vykazujú aj najnižšie hodnoty miery rizika (Bratislavský 7,80 \% a Trnavský 8,50\%). Uvedené kraje disponujú konkurenčnými a komparatívnymi výhodami pre vstup a efektívne využívanie (zahraničných) investícií, majú dynamicky sa rozvíjajúce ekonomické prostredie, relatívne stabilné pracovné trhy a koncentrujú obyvatel'stvo vyšších príjmových skupín. Miera rizika chudoby je najvyššia v Banskobystrickom (17,10 \%), Prešovskom (16 \%) a Košickom (13,70 \%) kraji s kumuláciou a synergickým efektom viacerých negatívnych faktorov (výrazná štrukturálna nerovnováha trhov práce s nadpriemernými mierami evidovanej a dlhodobej nezamestnanosti, koncentrácia marginalizovaných rómskych komunít a i.).

Indikátorom priestorovo diferencovanej úrovne sociálno-ekonomickej situácie je počet poberatel'ov dávok v hmotnej núdzi (Hanzelová 2015). Nadpriemerný počet poberatel'ov dávok v hmotnej núdzi na 1000 obyvatel'ov je v Banskobystrickom $(38,64)$, Košickom $(36,48)$ a Prešovskom $(27,89)$ kraji.

Súčast'ou hodnotenia regionálnych disparít pre oblast' l'udských zdrojov sú aj tzv. kontextové ukazovatele - počet účastníkov celoživotného vzdelávania na 100 obyvatel'ov vo veku 25 - 64 rokov a miera nezamestnanosti absolventov stredných škôl. Ked’že ide indikátory, ktoré majú bezprostrednú väzbu na podporované opatrenia OP Vzdelávanie, ich podrobnejšia analýza je súčast'ou d'alšej časti príspevku.

V rokoch 2007 a 2015 sú v oblasti l'udské zdroje podl'a analyzovaných ukazovatel'ov zretel'né regionálne rozdiely. Najvyšší počet bodov v oboch rokoch dosiahol Bratislavský kraj (rok 2007 800, rok 2015 830; tab. 1, obr. 1), ktorý si na konci analyzovaného obdobia posilnil svoju pozíciu v regionálnej štruktúre Slovenska. Dosahuje najpriaznivejšie hodnoty ukazovatel'ov demografického (migračný $9,73 \%$ a celkový prírastok obyvatel'stva 12,82 \%o, index vzdelanostnej úrovne 65,70 ) a sociálneho (miera rizika chudoby $7,80 \%$, počet poberatel'ov dávok v hmotnej núdzi 3,85 na 1000 obyv.) prostredia, trhu práce (miera evidovanej 5,34 $\%$ a dlhodobej nezamestnanosti $2,19 \%$, miera nezamestnanosti absolventov stredných škôl $8,90 \%$ ) a v porovnaní s priemerom SR $(1,94)$ výrazne vyšší počet účastníkov celoživotného vzdelania na 100 obyvatel'ov vo veku 25 - 64 rokov $(27,79)$.

V porovnaní s rokom 2007 sa bodové skóre ostatných krajov, s výnimkou výrazného ,prepadu“ Banskobystrického a viac-menej zachovanej pozície Košického kraja, zvýšilo (tab. 1). Najvýraznejší relatívny bodový posun zaznamenali nielen Trenčiansky (index rastu bodového skóre 122,07 \%), Trnavský $(108,06$ \%) a Žilinský $(106,39 \%)$ kraj, ale aj Nitriansky $(113,33$ \%) kraj. 
Tab. 1. Regionálne disparity v oblasti l’udských zdrojov (počet bodov)

\begin{tabular}{lccccccccc}
\hline & \multicolumn{7}{c}{ Región NUTS 3 (kraj) } \\
\cline { 2 - 9 } Rok & Bratislavský & Trnavský & Trenčiansky & Nitriansky & Žilinský & $\begin{array}{c}\text { Bansko- } \\
\text { bystrický }\end{array}$ & Prešovský & Košický \\
\hline 2007 & 800 & 335 & 222 & 120 & 219 & 83 & 131 & 173 \\
2015 & 830 & 362 & 271 & 136 & 233 & 44 & 137 & 174 \\
\hline
\end{tabular}

Zdroj: ŠÚ SR (2015), ÚPSVaR (2015), CVTI SR (2016), výpočty autorov.

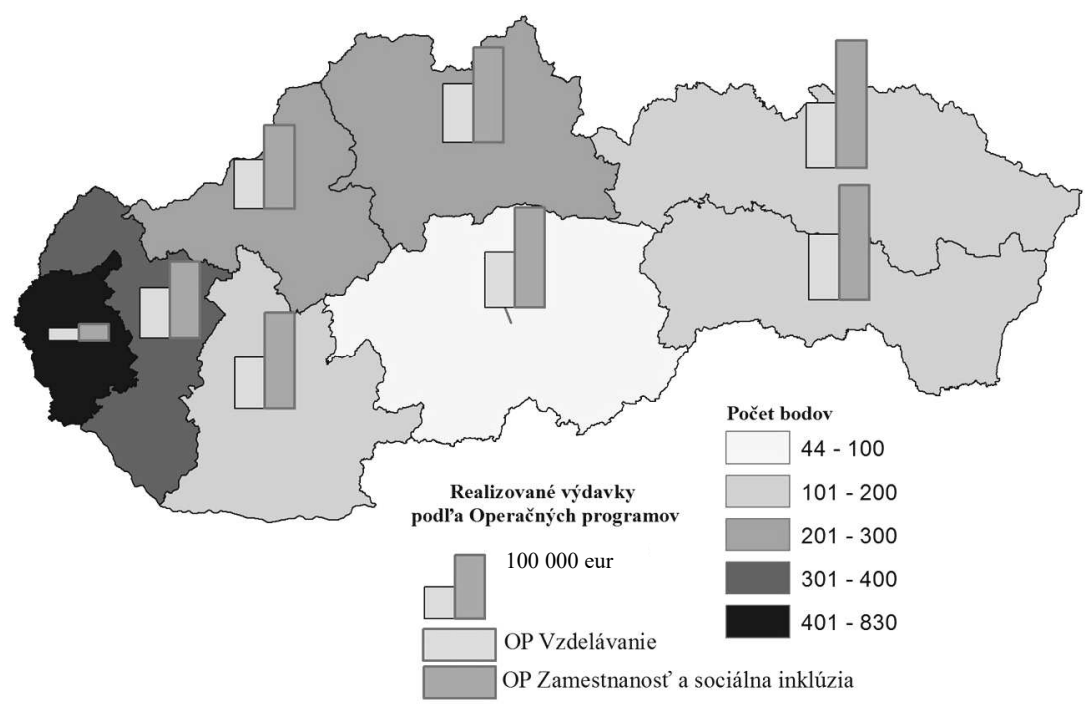

Obr. 1. Regionálne disparity a realizované výdavky z operačných programov Vzdelávanie a Zamestnanost' a sociálna inklúzia k 31. 12. 2015

V regionálnej štruktúre Slovenska má stabilne silnú pozíciu Trnavský kraj (362 bodov - tab. 1 a obr. 1), ktorého centrálna čast' je v širších súvislostiach súčast'ou rozsiahleho zázemia bratislavského pólu rozvoja najvyššej hierarchickej úrovne. Dlhodobo má relatívne vyrovnaný charakter demografických procesov, trhu práce s tvorbou pracovných príležitostí a podpriemernou mierou evidovanej $(5,34 \%)$ a dlhodobej nezamestnanosti (2,09\%), ako aj nezamestnanosti absolventov stredných škôl (13,80\%). Sociálno-ekonomické postavenie Trnavského kraja sa prejavuje aj v relatívne stabilnej sociálnej situácii obyvatel'stva, nízkej miere rizika chudoby $(8,50 \%)$ a počte poberatel'ov dávok v hmotnej núdzi na 1000 obyvatel'ov $(12,04)$. Druhá pozícia po Bratislavskom kraji je ovplyvnená nižšou vzdelanostnou úrovňou obyvatel'stva najmä v okrajových subregiónoch kraja.

Ďalšiu skupinu tvoria Trenčiansky ( 271 bodov) a Žilinský ( 233 bodov - tab. 1 a obr. 1) kraj, ktoré si v porovnaní s rokom 2007 posilnili svoju pozíciu v regionálnej štruktúre Slovenska. Ide o kraje s rozdielnym demografickým správaním, ktoré sa prejavuje nielen v diferencovanom celkovom prírastku, ale aj v starnutí obyvatel'stva Trenčianskeho kraja. Relatívne priaznivá sociálna úroveň odráža výkonnost' 
a prosperitu regionálnej ekonomiky a vyrovnaný charakter trhu práce (Švecová a Rajčáková 2014). Miery nezamestnanosti sú v oboch krajoch nižšie ako celoslovenský priemer, vzdelanostná štruktúra obyvatel'stva je priaznivá a odráža lokalizáciu stredných a vysokých škôl s moderným zameraním v súlade potrebami regionálneho hospodárstva. $\mathrm{O}$ stabilite ekonomického a sociálneho prostredia svedčia podpriemerné hodnoty analyzovaných mier nezamestnanosti, d'alej miera rizika chudoby a nízky počet poberatel'ov dávok v hmotnej núdzi. Počet účastníkov celoživotného vzdelávania na 100 obyvatel'ov vo veku 25 - 64 rokov je v oboch krajoch približne dvojnásobkom celoštátneho priemeru (Trenčiansky 4,32 a Žilinský 3,81).

Prešovský a Košický kraj dosiahli v roku 2015 porovnatel'ný počet bodov (tab. 1 a obr. 1). Dlhodobo nadpriemerný celkový prírastok obyvatel'stva sa prejavuje aj v indexe starnutia, ktorý je v oboch krajoch približne o štvrtinu nižší ako celoslovenský priemer. Pozícia krajov v regionálnej štruktúre je determinovaná slabšou výkonnost'ou regionálnej ekonomiky, problematickým trhom práce a nepriaznivou sociálnou situáciou predovšetkým segmentu marginalizovaných rómskych komunít (Švecová a Rajčáková 2014). Aj napriek úspešnej implementácii pomerne vysokého objemu prostriedkov v programovom období 2007 - 2015 na projekty zamerané na podporu a zvýšenie zamestnatel'nosti a sociálnu inklúziu kraje deklarujú nadpriemerné miery evidovanej a dlhodobej nezamestnanosti a nezamestnanosti absolventov stredných škôl, mieru rizika chudoby a vysoký počet poberatel'ov dávok v hmotnej núdzi. Poslednú pozíciu v regionálnej štruktúre Slovenska v oblasti l’udské zdroje v rokoch 2007 (83 bodov) aj 2015 (44 bodov) má Banskobystrický kraj (tab. 1 a obr. 1). Dlhodobý degresívny demografický vývoj sa prejavuje v prirodzenom a celkovom úbytku obyvatel'stva $(-3,58 \%$, podpriemerných hodnotách indexov starnutia $(103,76)$ a vzdelanostnej úrovne obyvatel'stva $(52,40)$. Trh práce Banskobystrického kraja patrí $\mathrm{k}$ najproblémovejším, s trvalo extrémnymi hodnotami miery evidovanej $(15,66 \%)$ a dlhodobej $(22,22 \%)$ nezamestnanosti, miery nezamestnanosti absolventov stredných škôl (16,73\%), na 100 obyvatel'ov vo veku 25 - 64 rokov pripadá len 2,22 účastníkov celoživotného vzdelania. Miera rizika chudoby $(17,10$ \%) je vôbec najvyššia medzi krajmi SR. Skvalitnenie a zabezpečenie sociálneho statusu l'udských zdrojov si vyžaduje komplexné a systémové riešenie, ktoré je možné realizovat' dôsledným uplatnením integrovaného prístupu alokácie a využívania zdrojov pomoci.

Štandardná miera regionálnych nerovností, Giniho koeficient, s výnimkou dvoch analyzovaných ukazovatel'ov (podiel poberatel'ov dávok v hmotnej núdzi z celkového počtu obyvatel'ov a počet účastníkov celoživotného vzdelávania na 100 obyvatel'ov vo veku 25 - 64 rokov) vypovedá o zmierňovaní regionálnych disparít podl'a krajov Slovenska (tab. 2). Avšak je potrebné uviest', že s výnimkou zníženia hodnoty miery evidovanej nezamestnanosti, ktorá je odrazom pozitívneho vývoja na trhu práce v pokrízovom období, prišlo k zhoršeniu hodnoty viacerých indikátorov. V regionálnej štruktúre Slovenska sa popri dominantnej pozícii Bratislavského kraja ,posilnila“ pozícia Trnavského, Trenčianskeho a Žilinského kraja, zachovala sa nepriaznivá pozícia Prešovského a Košického kraja, avšak v dôsledku synergického efektu spolupôsobenia viacerých negatívnych faktorov sa výrazne zhoršila pozícia Banskobystrického kraja (tab. 2). 
Tab. 2. Regionálne disparity v oblasti l'udských zdrojov

\begin{tabular}{|c|c|c|c|c|c|c|}
\hline \multirow{2}{*}{ Ukazovatele } & \multicolumn{2}{|c|}{ Variačné rozpätie } & \multicolumn{2}{|c|}{ Smerodajná odchýlka } & \multicolumn{2}{|c|}{ Giniho koeficient } \\
\hline & 2007 & 2015 & 2007 & 2015 & 2007 & 2015 \\
\hline $\begin{array}{c}\text { Migračný prírastok } \\
\text { (úbytok) obyvatel'stva (\%o) }\end{array}$ & 7,23 & 11,76 & 2,50 & 3,65 & - & - \\
\hline $\begin{array}{c}\text { Celkový prírastok } \\
\text { (úbytok) obyvatel'stva (\%o) }\end{array}$ & 8,40 & 16,40 & 2,52 & 4,91 & - & - \\
\hline Index starnutia (\%) & 41,63 & 49,43 & 14,56 & 16,81 & 0,1652 & 0,1597 \\
\hline $\begin{array}{l}\text { Index vzdelanostnej úrovne } \\
\text { obyvatel'stva }\end{array}$ & 24,00 & 32,63 & 7,33 & 9,95 & 0,1260 & 0,1358 \\
\hline $\begin{array}{c}\text { Miera evidovanej } \\
\text { nezamestnanosti }(\%)\end{array}$ & 12,12 & 10,16 & 4,29 & 3,74 & 0,3673 & 0,2627 \\
\hline $\begin{array}{c}\text { Miera dlhodobej } \\
\text { nezamestnanosti (\%) }\end{array}$ & 8,76 & 8,45 & 3,17 & 3,36 & 0,4494 & 0,3587 \\
\hline $\begin{array}{l}\text { Miera nezamestnanosti } \\
\text { absolventov stredných škôl }\end{array}$ & 9,06 & 9,64 & 2,70 & 2,82 & 0,2001 & 0,1617 \\
\hline Miera rizika chudoby $(\%)$ & 9,70 & 9,30 & 3,13 & 3,30 & 0,2337 & 0,2111 \\
\hline $\begin{array}{l}\text { Počet účastníkov celoživotného } \\
\text { vzdelávania na } 100 \text { obyv. vo } \\
\text { veku } 25 \text { - } 64 \text { rokov }\end{array}$ & 28,36 & 26,53 & 8,40 & 8,27 & 0,4190 & 0,5013 \\
\hline $\begin{array}{c}\text { Podiel poberatel'ov dávok } \\
\text { v hmotnej núdzi z celkového } \\
\text { počtu obyv. }(\%)\end{array}$ & 4,19 & 4,12 & 1,42 & 1,38 & 0,3077 & 0,3919 \\
\hline
\end{tabular}

Zdroj: ŠÚ SR (2015), ÚPSVaR (2015), CKO (2016), CVTI SR (2016) MŠVVŠ SR (2015), výpočty autorov.

\section{PODPORA L'UDSKÝCH ZDROJOV V RÁMCI POLITIKY SÚDRŽNOSTI $2007-2013$}

Ako vyplýva z analýzy, úroveň l’udských zdrojov je na Slovensku značne diferencovaná. Jedným z významných nástrojov na vyrovnávanie regionálnych disparít v oblasti l'udských zdrojov sú štrukturálne fondy EÚ, ktorých čerpanie sa v rokoch 2007 - 2013 (2015) realizovalo prostredníctvom implementácie Národného strategického a referenčného rámca. Oblast' l'udských zdrojov bola súčast'ou strategickej priority 3 a jej podpora sa uskutočnila z OP Vzdelávanie a OP Zamestnanost' a sociálna inklúzia. Ciel’om bolo zvýšenie zamestnanosti, rast kvality pracovnej sily pre potreby vedomostnej spoločnosti a zvýšenie sociálnej inklúzie rizikových skupín obyvatel'stva. Na jednej strane podpora smerovala do oblasti moderného vzdelávania a na prispôsobenie vzdelávacieho systému potrebám vedomostnej spoločnosti. Finančné intervencie smerovali do reformy vzdelávania, so zameraním na kvalitu obsahu a procesov vzdelávania tak, aby vzdelávacie inštitúcie pripravovali absolventov schopných flexibilne plnit' požiadavky a potreby trhu práce a na celoživotné vzdelávanie (špecifická priorita 3.1). Na druhej strane intervencie boli orientované na rast zamestnanosti a sociálnej inklúzie a zníženie nezamestnanosti. Podporené boli projekty zamerané na znižovanie miery nezamestnanosti v zaostávajúcich regiónoch SR, realizáciu aktívnych opatrení trhu práce s ciel'om zvyšovania kvality l'udských zdrojov a riešenie problémov sociálnej inklúzie osôb s osobi- 
tými vzdelávacími potrebami so zretel'om na marginalizované rómske komunity (špecifická priorita 3.2).

K 31. 12. 2015 realizované výdavky na podporu rozvoja l'udských zdrojov predstavovali 1,65 mld. eur, ktoré boli implementované v rámci 2652 národných a dopytovo orientovaných projektov. Na podporu vzdelávania smerovalo 648 mil. eur (37\% z celkovej sumy; 1092 projektov) a na podporu zamestnanosti 1,107 mil. eur (63\% z celkovej sumy, 1560 projektov). Projekty boli spolufinancované podl'a územnej oprávnenosti vo všetkých krajoch Slovenska (obr. 2).

a)

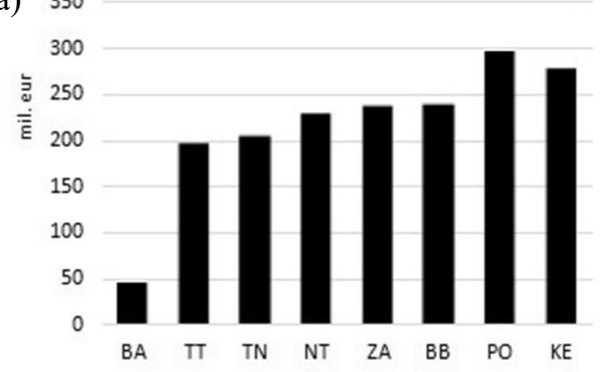

b) 800

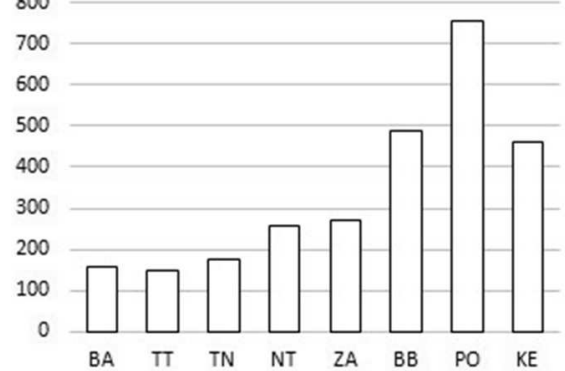

Obr. 2. Implementácia strategickej priority 3. L'udské zdroje podl’a krajov SR k 31. 12. 2015.

a - realizované výdavky ŠF v PO 2007 - 2013, b - počet zazmluvnených projektov v PO $2007-2013$

Zdroj: CKO (2016), výpočty autorov.

Územná realizácia výdavkov určených na podporu projektov bola značne diferencovaná a nie vždy v súlade s regionálnymi disparitami. Najviac finančných prostriedkov smerovalo do Prešovského (295 mil. eur; 753 projektov), Košického (276,6 mil. eur; 461 projektov), Banskobystrického (238,6 mil. eur; 488 projektov) a Žilinského (237 mil. eur; 271 projektov) kraja, najnižšia intervencia smerovala do Bratislavského kraja (46,5 mil. eur; 158 projektov), ktorý z dlhodobého hladiska dosahuje najnižšie miery nezamestnanosti a rizika chudoby a nízky podiel sociálne odkázaných osôb (obr. 2).

\section{Operačný program Vzdelávanie}

V oblasti podpory vzdelávania pozornost' bola upriamená hlavne na premenu tradičnej školy na modernú (opatrenie 1.1 a 4.1) prostredníctvom uskutočnenia obsahovej prestavby vzdelávania na základných a stredných školách a prípravu absolventov v súlade s aktuálnymi a perspektívnymi potrebami vedomostnej spoločnosti.

Rámcové aktivity mali za úlohu zvýšit' kvalitu klúčových kompetencií a zručností žiakov prostredníctvom podpory reformy a rozvoja všeobecného a odborného vzdelávania na základných a stredných školách; podpory výchovného a kariérneho poradenstva na ZŠ a SŚ; podpory prípravy učitel'ov a d'alšieho vzdelávania pedagogických zamestnancov; podpory systému otvorenej školy; podpory a rozvoja nástrojov hodnotenia výchovno-vzdelávacích činností škôl a školských zariadení. 
Podporených bolo 764 projektov v celkovom objeme 311,2 mil. eur (takmer $50 \%$ z OP Vzdelávanie), v rámci ktorých bolo novovytvorených 976 vzdelávacích programov, ktoré mali zvýšit' kl'účové kompetencie a zručnosti žiakov základných a stredných škôl.

Úspešnost' obsahovej prestavby vzdelávania základného a stredného školstva v súlade $\mathrm{s}$ aktuálnymi potrebami možno hodnotit' prostredníctvom miery uplatnitel'nosti, resp. nezamestnanosti absolventov stredných škôl (gymnáziá, SOS, špeciálne stredné školy a konzervatóriá), ktorá je vyjadrením absorpčnej kapacity regionálnych trhov práce pre stredoškolsky vzdelaných absolventov SŠ. V roku 2015 bolo na Slovensku 55,42 tis. absolventov stredných škôl, čo je v porovnaní s rokom 2007 o 14,5 tis. menej. Vývoj miery nezamestnanosti absolventov stredných škôl korešponduje s vývojom celkovej nezamestnanosti (Kostolná et al. 2010). Avšak aj napriek pozitívnemu vývoju celkovej nezamestnanosti v rokoch 2007 - 2015 sa problémy v uplatnení absolventov SS na trhu práce prehlbujú a v priestorovej diferenciácii sa prejavujú značné regionálne rozdiely. V roku 2015 v porovnaní s rokom 2007 vzrástol počet UoZ - absolventov SS na Slovensku o 4,2 tis. (zo 16,4 tis. na 20,6 tis.) a miera ich nezamestnanosti vzrástla z 23,49 \% na 37,21 \%.

Finančná podpora z ESF na realizáciu projektov však nekorešpondovala s priestorovou diferenciáciou nezamestnanosti absolventov SŠ (tab. 3).

Tab. 3. Miera nezamestnanosti absolventov stredných škôl a výška realizovaných výdavkov na podporu opatrenia 1.1 OP Vzdelávanie

\begin{tabular}{lcccccccccc}
\hline Ukazovatel/Kraj & BA & TT & TN & NT & ZA & BB & PO & KE & SR & $\begin{array}{c}\text { Giniho } \\
\text { koeficient }\end{array}$ \\
\hline $\begin{array}{l}\text { Miera nezamestnanosti } \\
\text { absolventov SS (\%) - } \\
\text { rok 2007 }\end{array}$ & 4,84 & 10,02 & 9,22 & 10,22 & 9,77 & 12,79 & 13,90 & 13,17 & 10,63 & 0,2001 \\
$\begin{array}{l}\text { Miera nezamestnanosti } \\
\text { absolventov SŠ (\%)- } \\
\text { rok 2015 }\end{array}$ & 8,90 & 15,38 & 13,80 & 14,24 & 15,14 & 16,73 & 18,54 & 17,93 & 15,40 & 0,1617 \\
$\begin{array}{l}\text { Výška realizovaných } \\
\text { výdavkov zo ŠF } \\
\text { v rokoch 2007-2015 } \\
\text { (mil. eur) }\end{array}$ & 0 & 20,185 & 23,966 & 23,742 & 30,699 & 26,452 & 33,685 & 30,909 & 189,638 \\
\hline
\end{tabular}

Zdroj: ŠÚ SR (2015), CKO (2016), CVTI SR (2016), MŠVVŠ SR (2015), výpočty autorov.

Druhou významnou oblast'ou bola podpora d’alšieho vzdelávania (opatrenia 2.1 a 2.2), ktorej ciel'om bolo prispiet' $\mathrm{k}$ vytvoreniu a rozvoju efektívneho systému celoživotného vzdelávania na Slovensku s dôrazom na rozvoj klúčcových kompetencií a prehlbovanie kvalifikácie zamestnancov. Zvýšenie kvality a kapacity systému celoživotného vzdelávania má viest' $\mathrm{k}$ zvýšeniu podielu ekonomicky aktívnych obyvatel'ov, účastníkov celoživotného vzdelávania.

Implementácia 69 projektov v objeme realizovaných výdavkov 147,4 mil. eur sa realizovala vo všetkých krajoch okrem Bratislavského. Podporených bolo 762 programov celoživotného vzdelávania, ktorých sa zúčastnilo približne $3 \%$ obyvatel'ov vo veku 25 - 64 rokov, čo je však o $9,43 \%$ menej ako sa predpokladalo (výročná správa OP Vzdelávanie 2015). Pokles záujmu o celoživotné vzdelávane dokumentuje aj vývoj počtu účastníkov celoživotného vzdelávania v rokoch 2007 2015 , ked' ich počet poklesol z 332,48 tis. na 256,76 tis., približne o štvrtinu. 
Ďalšie finančné prostriedky smerovali na podporu efektívnej medzinárodnej spolupráce, na zapojenie vysokých škôl do sietí výskumu a vývoja, mobilitu študentov a pedagógov (opatrenia 1.2 a 4.2), zvyšovanie vzdelanostnej úrovne osôb so špeciálnymi výchovno-vzdelávacími potrebami, ako aj na zvyšovanie vzdelanostnej úrovne marginalizovaných rómskych komunít (opatrenia 3.1 a 3.2), ktoré sa realizovali predovšetkým v krajoch s najvyšším podielom rómskej populácie.

Tab. 4. Počet účastníkov celoživotného vzdelávania a výška realizovaných výdavkov na podporu opatrení 2.1. a 2.2 OP Vzdelávanie

\begin{tabular}{|c|c|c|c|c|c|c|c|c|c|c|}
\hline Ukazovatel'/Kraj & BA & $\mathrm{TT}$ & $\mathrm{TN}$ & NT & ZA & $\mathrm{BB}$ & $\mathrm{PO}$ & $\mathrm{KE}$ & SR & $\begin{array}{c}\text { Giniho } \\
\text { koeficient }\end{array}$ \\
\hline $\begin{array}{l}\text { Počet účastníkov } \\
\text { CŽV na } 100 \\
\text { obyvatel'ov vo } \\
\text { veku } 25-64 \text { rokov } \\
\text { - rok } 2007\end{array}$ & 31,94 & 3,58 & 10,26 & 4,67 & 6,73 & 11,68 & 10,53 & 7,46 & 10,86 & 0,4190 \\
\hline $\begin{array}{l}\text { Počet účastníkov } \\
\text { CŽV na } 100 \\
\text { obyvatel'ov vo } \\
\text { veku } 25-64 \text { rokov } \\
\text { - rok } 2015\end{array}$ & 27,79 & 3,57 & 4,32 & 3,65 & 3,81 & 2,11 & 1,26 & 1,94 & 8,27 & 0,5013 \\
\hline $\begin{array}{l}\text { Výška realizova- } \\
\text { ných výdavkov zo } \\
\text { ŠF (mil. eur) } \\
2007-2015\end{array}$ & 0 & 21,16 & 20,91 & 20,91 & 20,27 & 20,78 & 22,59 & 20,75 & 147,43 & \\
\hline
\end{tabular}

Vysvetlivky: CŽV - celoživotné vzdelávanie, ŠF - štrukturálne fondy. Zdroj: ŠÚ SR (2015), CKO (2016), CVTI SR (2016), výpočty autorov.

a) 120

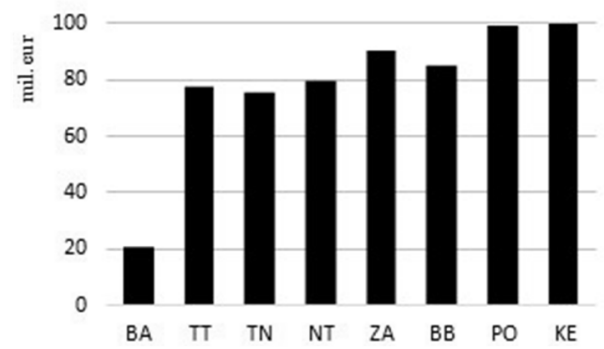

b) 300

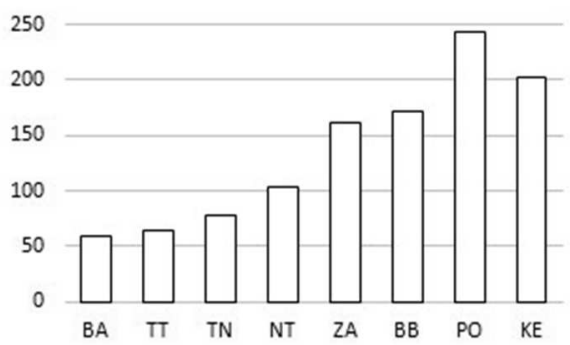

Obr. 3. Implementácia OP Vzdelávanie podl’a krajov SR k 31. 12. 2015 a - realizované výdavky ŠF v PO 2007 - 2013, b - počet zazmluvnených projektov v PO $2007-2013$

Vysvetlivky: ŠF - štrukturálne fondy, PO - programové obdobie Zdroj: CKO (2016), výpočty autorov.

Priestorová diferenciácia realizovaných výdavkov poukazuje na značné regionálne rozdiely. V rámci OPV najviac finančných prostriedkov bolo realizovaných v Košickom (100,4 mil. eur; 203 projektov), Prešovskom (99,5 mil. eur; 244 projektov), Žilinskom (90,6 mil. eur; 162 projektov), Banskobystrickom (84,9 mil. eur; 171 projektov) a Nitrianskom (79,7 mil. eur; 103 projektov) kraji. Nasledovali Trnavský (77,7 mil. eur; 65 projektov), Trenčiansky (75,4 mil. eur; 78 projektov) a Bratislavský (20,3 mil. eur; 59 projektov) kraj (obr. 3). 
Operačný program Zamestnanost' a sociálna inklúzia

V oblasti zamestnanosti bola pozornost' upriamená na riešenie významných problémov SR na trhu práce, a to najmä na nízku mieru zamestnanosti, vysokú mieru nezamestnanosti so zretel'om na dlhodobo nezamestnaných, mladých nezamestnaných a absolventov škôl.

Kl'účovou skupinou nástrojov na tvorbu nových pracovných miest a umiestnenie nezamestnaných osôb, resp. osôb, ktorým hrozilo prepúšt’anie z pracovného pomeru na vol'né pracovné miesta boli nástroje aktívnej politiky trhu práce zamerané na zvyšovanie zamestnatel'nosti a podporu tvorby pracovných miest. Podporovali sa aktivity smerujúce $\mathrm{k}$ zlepšeniu prístupu k zamestnaniu, prevencii dlhodobej nezamestnanosti, zachovaniu pracovných návykov vrátane proaktívnych nástrojov zameraných na predchádzanie, resp. zmierňovanie vylúčenia z dôvodu zdravotného znevýhodnenia. Podporovaný bol výber vhodných aktivít na integráciu znevýhodnených uchádzačov do udržatel'ného zamestnania. Preferovali sa aktivity, ktoré motivovali nezamestnaných a dlhodobo nezamestnaných v snahe o integráciu na trh práce. Sekundárnym ciel'om bolo udržanie pracovných návykov.

Podporených bolo 43 projektov na národnej a nadregionálnej úrovni v celkovej hodnote realizovaných výdavkov 767 mil. eur (takmer $70 \%$ celkovej alokácie OP ZaSI, opatrenie 1.1), a 596 dopytovo orientovaných projektov vo výške 97,38 mil. eur (opatrenia 1.2 a 3.1). Prostredníctvom implementácie opatrení sa vytvorilo takmer 78 tisíc pracovných miest a prácu si udržalo takmer štyri tisíc osôb.

Jedným z relevantných ukazovatel'ov vyjadrujúcich efektivitu vynaložených prostriedkov na riešenie problémov trhu práce sú zmeny hodnôt ukazovatel'ov miery evidovanej a dlhodobej nezamestnanosti, podrobnejšie analyzované v predchádzajúcej časti príspevku.

Tab. 5. Miera nezamestnanosti a výška realizovaných výdavkov $z$ opatrení 1.1, 1.2. a 3.1 OP Zamestnanost' a sociálna inklúzia

\begin{tabular}{|c|c|c|c|c|c|c|c|c|c|c|}
\hline Ukazovatel'/Kraj & $\mathrm{BA}$ & $\mathrm{TT}$ & $\mathrm{TN}$ & NT & $\mathrm{ZA}$ & BB & $\mathrm{PO}$ & KE & SR & $\begin{array}{c}\text { Giniho } \\
\text { koeficient }\end{array}$ \\
\hline $\begin{array}{l}\text { Miera evidovanej } \\
\text { nezamestnanosti (\%) } \\
\text { - rok } 2007\end{array}$ & 1,98 & 4,30 & 4,50 & 7,10 & 5,55 & 14,10 & 12,05 & 13,02 & 7,83 & 0,3673 \\
\hline $\begin{array}{l}\text { Miera evidovanej } \\
\text { nezamestnanosti (\%) } \\
\text { - rok } 2014\end{array}$ & 6,13 & 8,03 & 9,56 & 11,21 & 10,91 & 17,22 & 17,45 & 15,92 & 12,05 & 0,2499 \\
\hline $\begin{array}{l}\text { Miera dlhodobej } \\
\text { nezamestnanosti (\%) } \\
\text { - rok } 2014\end{array}$ & 2,33 & 3,59 & 4,87 & 6,38 & 5,87 & 12,09 & 12,08 & 11,32 & 7,32 & 0,3415 \\
\hline
\end{tabular}

Zdroj: ŠÚ SR (2015), ÚPSVaR (2015), CKO (2016) výpočty autorov.

Ostatné opatrenia boli orientované na posilnenie sociálnej inklúzie a integráciu osôb ohrozených sociálnym vylúčením s osobitným zretel’om na marginalizované rómske komunity (prioritná os 2) a na budovanie kapacít a zlepšenie služieb verejnej správy (prioritná os 4 ). 
Celkove z OP ZaSI bolo prefinancovaných 1,107 mil. eur v 1629 projektoch diferencovane podl'a krajoch Slovenska. Podpora v najvyššej miere smerovala do Prešovského (195,7 mil. eur; 753 projektov) a Košického (176,2mil. eur; 258 projektov) kraja, kde realizované výdavky dosiahli až o $20 \%$ vyššie alokácie ako V najproblémovejších regiónoch Slovenska, v Banskobystrickom (153,6 mil. eur; 317 projektov) a Nitrianskom (149,1 mil. eur; 259 projektov) kraji, ktoré dlhodobo vykazujú nepriaznivý stav nezamestnanosti. Najnižšia alokácia 26,1 mil. eur (99 projektov) smerovala do Bratislavského kraja (obr. 4).
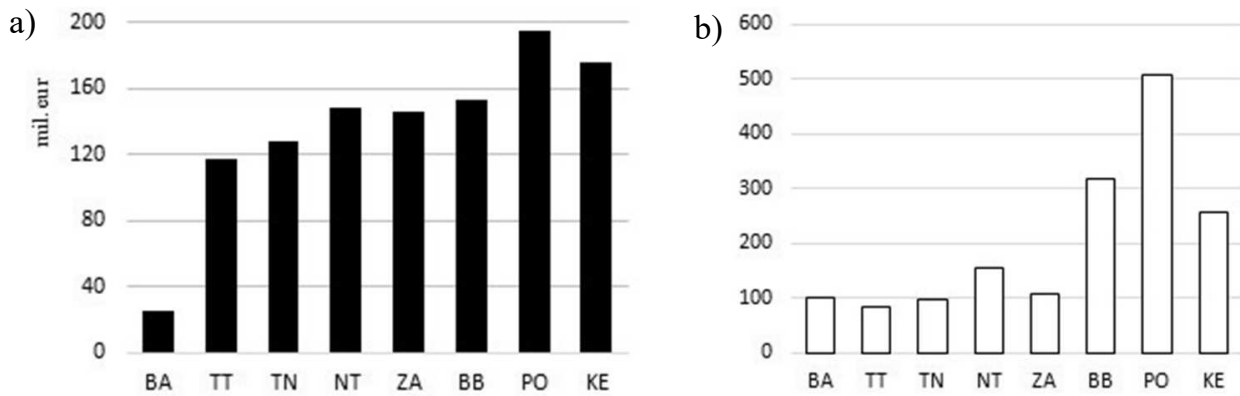

Obr. 4. Implementácia OP Zamestnanost’ a sociálna inklúzia podl’a krajov SR k 31. 12. 2015

a - realizované výdavky ŠF v PO 2007 - 2013, b - počet zazmluvnených projektov v PO $2007-2013$

Zdroj: CKO (2016), výpočty autorov.

\section{DISKUSIA A ZÁVER}

Stav regionálnej štruktúry so znakom regionálnych disparít je výsledkom spolupôsobenia viacerých faktorov (priestorovo diferencovaný demografický vývoj a štruktúra obyvatel'stva, trh práce, vývoj (makro-)ekonomického a sociálneho prostredia a i.) a ovplyvnený aj využívaním nástrojov regionálnej politiky v oblasti l'udských zdrojov.

Analýza vývoja a stavu regionálnych disparít podl'a vybraných ukazovatel'ov l'udských zdrojov na úrovni krajov Slovenska preukázala zmierňovanie regionálnych rozdielov. $\mathrm{V}$ oboch analyzovaných rokoch najlepšiu pozíciu $\mathrm{v}$ regionálnej štruktúre Slovenska podl'a hodnotených ukazovatel'ov majú Bratislavský (rok 2007 - 800 bodov, rok 2015 - 830 bodov) a Trnavský kraj (rok 2007 - 335 bodov, rok 2015 - 362 bodov). V porovnaní s rokom 2007 si pomerne silnú pozíciu zachovali Trenčiansky, Žilinský a Nitriansky kraj, pozícia Prešovského a Košického kraja zostala viac-menej zachovaná. Avšak výrazne sa oslabila pozícia Banskobystrického kraja, ktorý má nepriaznivý demografický vývoj a štruktúru obyvatel'stva v súlade s potrebami regionálneho trhu práce, ktorý spolu trhom práce Košického a Prešovského kraja, patrí k najproblémovejším s výraznou štrukturálnou nerovnováhou. Postavenie kraja je dané aj nepriaznivými stavom sociálneho prostredia s dlhodobo vysokým podielom poberatel’ov dávok $\mathrm{v}$ hmotnej núdzi a mierou rizika chudoby.

Na riešenie problémov l'udských zdrojov boli v rámci politiky súdržnosti 2007 - 2013 určené finančné zdroje ESF v rámci strategickej priority 3. L’udské zdroje 
NSRR. V súlade $\mathrm{s}$ územnou oprávnenost’ou boli čerpané na národné a dopytovo orientované projekty $\mathrm{v}$ rámci dvoch operačných programov - Zamestnanost' a sociálna inklúzia a Vzdelávanie vo všetkých krajoch Slovenska. Najvyššie čerpanie implementovaných projektov bolo v Prešovskom (295,2 mil. eur) a Košickom (276,6 mil. eur) kraji, kým v Banskobystrickom (238,6 mil. eur) a Nitrianskom (228,8 mil. eur) kraji, ktoré patria k najproblémovejším, čerpanie oprávnených prostriedkov na podporu l'udských zdrojov a sociálnu inklúziu bolo približne o $20 \%$ nižšie (obr. 1).

Zhodnotit' príspevok ŠF k zmierneniu regionálnych disparít je vel'mi problematické. Aj ked' sa preukázalo zmiernenie regionálnych disparít v oblasti l’udských zdrojov, hodnota viacerých čiastkových ukazovatel'ov, ktoré boli v hodnotení zohl'adnené, indikujú nepriaznivý vývoj. Samotná implementácia finančných prostriedkov nie vždy odrážala reálne potreby regiónov (krajov) a oblasti podpory, ktorých ciel'om malo byt' zníženie nezamestnanosti, zvýšenie zamestnanosti, rozšírenie kompetenčných zručností pracovných zdrojov, zvýšenie ich adaptability na trhu práce a $\mathrm{v}$ neposlednom rade riešenie sociálnej inklúzie. Na druhej strane je však potrebné uviest', že implementované boli neinvestičné projekty, ktorých reálny prínos sa spravidla prejaví až s istým časovým oneskorením po samotnej implementácii. Územná alokácia podpory nedostatočne reflektovala špecifické potreby regiónov a regionálne rozdiely.

Smerovanie podpornej regionálnej politiky v oblasti l'udské zdroje v programovom období 2014 - 2020 si vyžaduje nielen zohl'adnenie potrieb regiónov a adresnejšiu územnú alokáciu zdrojov, ale aj vytvorenie podmienok pre zvýšenú absorpčnú kapacitu najmä problémových regiónov a aktívnu súčinnost' aktérov regionálnej politiky na všetkých hierarchických úrovniach.

Príspevok je súčastou riešenia grantového projektu VEGA 1/0540/16 Sociálne, ekonomické a environmentálne determinanty rozvoja a transformácie regiónov: regionálnogeografický prístup.

\section{LITERATÚRA}

BACHTLER, J., McMASTER, I. (2008). EU Cohesion policy and the role of the regions: investigating the influence of Structural Funds in the new member states. Environment and Planning C: Politics and Space, 26, 398-427.

BACHTLER, J., WREN, T. (2006).The evaluation of EU cohesion policy: research questions and policy challenges. Regional Studies, 40, 143-153.

BLAŽEK, J., UHLIŘ, D. (2011). Teorie regionálního rozvoje. Praha (Univerzita Karlova).

BLEHA, B., ŠPROCHA, B., VAŇO, B. (2014). Demografická prognóza okresov Slovenska do roku 2035 v kontexte odhal'ovania geografickej nerovnomernosti a konvergencie. Acta Geographica Universitatis Comenianae, 58, 11-44.

BUČEK, M., REHÁK, Š, TVRDOŇ, J. (2010). Regionálna ekonómia a politika. Bratislava (Ekonomická univerzita).

CACE, C., CACE, S., IOVA, C., NICOLÄESCU, V. (2009). Absorption capacity of the structural funds. Integrating perspectives, [Online]. Dostupné na: http://www.rcis.ro/ images/documente/rcis27_01.pdf [cit: 15-6-2017].

CKO (2016). Stav implementácie SF podl'a OP, priorit a opatrení pre PO 2007-2013 $k$ 31.12.2015, [Online]. Dostupné na: http://www.nsrr.sk/cerpanie/ [cit: 16-6-2016].

CVTI SR (2016). Prehl'ady absolventov stredných škôl podl'a krajov SR $k$ 30.9.2007 a 2015, [Online]. Dostupné na: http://www.cvtisr.sk/cvti-sr-vedecka-kniznica/informacieo-skolstve/statistiky.html?page id $=9230$ [cit: 22-6-2017]. 
DUBOIS, A. (2007). Regional disparities and cohesion: what strategies for the future, [Online]. Dostupné na: http://edz.bib.uni-mannheim.de/daten/edz-ma/ep/07/pe379.205en.pdf [cit: 4-1-2015].

DVORAK, J. (2010). Evaluation of the European Union structural funds' support in Poland: scope and significance. Baltic Journal of Law \& Politics, 3, 53-75.

GAJDOŠ, P. (2005). Teoretický a metodologický rámec klasifikácie a typológie regiónov Slovenska v kontexte teritoriálnych disparít. In Ira, V., Pašiak, J., Falt'an, L., Gajdoš, P., eds. Podoby regionálnych odlišností na Slovensku. Bratislava (Sociologický ústav SAV).

HAMPL, M. (2005). Geografická organizace společnosti v České republice: transformační procesy a jejich obecný kontext. Praha (Univerzita Karlova v Praze).

HANZELOVÁ, E. (2015). Pomoc v hmotnej núdzi: vývoj základných ukazovatel'ov. Bratislava (Inštitút pre výskum práce a rodiny).

HERICH, J. (2014). Prognóza vývoja ukazovatel'ov stredných škôl do roku 2025, [Online]. Dostupné na: http://www.cvtisr.sk/cvti-sr-vedecka-kniznica/informacie-o-skolstve/ publikacie-casopisy.../analyzy-prognozy-studie.html?page id=9238 [cit: 31-5-2017].

HUDEC, O., URBANČIKOVÁ, N., DŽUPKA, P., ŠEBOV̄Á, M., KLIMOVSKÝ, D., SUHÁNYI, L., ȚELINSKÝ, T. (2009). Podoby regionálneho a miestneho rozvoja. Košice (Ekonomická fakulta TU Košice).

CHABIČOVSKÁ, K., GALVASOVÁ, I., BINEK, J., HOLEČEK, J., PŘIBYLÍKOVÁ, A. (2009). Rozvojový interaktivní audit. Brno (GaREP, spol. s r. o.).

KOREC. P. (2005). Regionálny rozvoj Slovenska v rokoch 1989 - 2004. Bratislava (Univerzita Komenského).

KOREC, P., ONDOŠ, S. (2008). Regional development of the Slovak Republic from 1997 to 2006. In Gajdoš, P., eds. Regional disparities in Central Europe. Bratislava (Sociologický ústav SAV).

KOSTOLNĂ, Z., HANZELOVÁ, E., HERICH, L., SRNÁKOVÁ, L. (2010). Nezamestnanost' absolventov škôl a prístupy $k$ jej riešeniu v členských štátoch EU v období globálnej ekonomickej krizy, [Online]. Dostupné na: http://www.ceit.sk/IVPR/images/IVPR/ vyskum/2010/Kostolna/VU 2146 Kostolna.pdf [cit: 28-7-2017].

LUBYOVÁ, M., S̈TEFÁNIK, M., BĀBOS̃, P., GERBERY, D., HVOZDÍKOVÁ, V., KARASOVÂ, K., LICHNER, I., MIKLOŠOVIČ, T., RADVANSKÝ, M., RUBLÍKOVÁ, E., STUDENA, I. (2015). Trh práce na Slovensku 2016+, [Online]. Dostupné na: http:// www.prog.sav.sk/fileadmin/pusav/download files/novinky/Monografia_Lubyova_ Stefanik a kolektiv naweb.pdf [cit: 28-7-2017].

KUTSCHERAUER, A. (2007). Východiska výskumu regionálních disparit v územní rozvoji České republiky. Regionální disparity, 1, 6-12, [Online]. Dostupné na: http:// disparity.vsb.cz [cit: 21-2-2014],

MATLOVIČ, R., MATLOVIČOVÁ, K. (2011). Regionálne disparity a ich riešenie na Slovensku v rozličných kontextoch. Folia Geographica, 53, 8-87.

MATLOVIČOVÁ, K., ŽIDOVÁ, A., KOLESÁROVÂ, J. (2014). Dynamika regionálnych disparít na Slovensku v predkrízovom období a ich riešenie vybranými nástrojmi regionálnej politiky. Geographia Slovaca, 28, 63-100.

MICHAELI, E., MATLOVIČ, R., IŠTOK, R., KLAMÁR, R., HOFIERKA, J., MINTÁLOVÁ, T., MITRÍKOVÁ, J. (2010). Regionálny rozvoj pre geografov. Prešov (Prešovská univerzita v Prešove).

MOHL, P., HAGENT, T. (2010). Do EU structural funds promote regional growth? New evidence from various panel data approaches. Regional Science and Urban Economics, 40, 353-365.

MOLLE, W. (2007). European cohesion policy. London (Routledge).

MŠVVŠ SR (2015). Výročná správa o vykonávaní Operačného programu Vzdelávanie za obdobie január - december 2014, [Online]. Dostupné na: https://www.minedu.sk/ vyrocna-sprava-op-vzdelavanie-za-rok-2014/ [cit: 10-6-2017]. 
NÁRODNÝ STRATEGICKÝ REFERENČNÝ RÁMEC (2007). [Online]. Dostupné na: http://www.nsrr.sk/dokumenty/zakladne-dokumenty/ [cit: 5-12-2014].

RAJČÁKOVÁ, E., ŠVECOVÁ, A. (2011). Regionálna štruktúra Slovenska v posledných troch desat'ročiach. Acta Regionalia et Environmentalica, 8(2), 29-37.

ŠVECOVÁ, A., RAJĆÁKOVÂ, E. (2014). Regionálne disparity v sociálno-ekonomickej úrovni regiónov Slovenska v rokoch 2001 - 2013. In Lauko, V., et al., Regionálne dimenzie Slovenska. Bratislava (Univerzita Komenského v Bratislave), pp. 257-294.

ŠÚ SR (2015). Pohyb, veková a vzdelanostná štruktúra obyvatel'stva podl'a krajov SR, [Online]. Dostupné na: http://px-web.statistics.sk/PXWebSlovak/ [cit: 1-6-2016].

ÚPSVaR (2015). Počet poberatel'ov sociálnych dávok podl'a krajov SR v rokoch 2007 a 2015, [Online]. Dostupné na: http://www.upsvar.sk/statistiky/socialne-veci-statisti ky.html?page id=10826 [cit: 15.6-2016].

VAÑ̃, B. (2002). Prognóza vývoja rómskeho obyvatel'stva v SR do roku 2025, [Online]. Dostupné na: http://www.infostat.sk/vdc/pdf/prognoza2025rom.pdf [cit: 3-5-2015].

VITURKA, M. (2010). Regionální disparity a jejich hodnocení v kontextu regionální politiky. Geografie, 2, 131-143.

WOKOUN, R., MALINOVSKÝ, J., DAMBORSKÝ, M., BLAŽEK, J. (2008). Regionální rozvoj, východiska regionálního rozvoje, regionální politika, teorie, strategie a programování. Praha (Linde).

Eva Raj čáková, Angelika Švecová

\section{HUMAN RESOURCES: REGIONAL DISPARITIES IN CONTEXT OF THE EU COHESION POLICY 2007 - 2013 IN SLOVAKIA}

The regional disparities, which are also evident in human resources, are a typical feature of the regional structure of Slovakia. They result in different demographic behaviour, labour market and social environment. Analysis of regional disparities highlighted the dominance of the Bratislava region, which reached the highest point score throughout the period 2007 - 2013 (Fig. 1). The Trnava region assumed second position. In 2013, the lowest quality of human resources was in Banska Bystrica, Prešov, Košice and the Nitra region (Fig. 1). The reasons are regressive demographic trends (Banska Bystrica and the Nitra region), an unfavourable situation in the labour market (permanently above average rate of overall and long-term unemployment - Prešov and Košice region), the poverty risk rate and a high proportion of socially dependent people, which leads to the threat of even social exclusion.

The Cohesion Policy 2007 - 2013 and its strategic priority 3 Human Resources, are one of the tools that can be used to reduce regional disparities in the field of human resources. The aim is employment growth, increasing the quality of the workforce and social inclusion of risk groups. All regions of the Slovak Republic are eligible in the area for the project implementation which can receive support from the ESF through two operational programs - OP Employment and Social Inclusion and OP Education. The SR had the opportunity to use 1.77 billion Euros from the European Social Fund under specific priority 3 Human Resources of NSRF 2007 - 2013. Expenditure incurred in support of strategic priority $3 \mathrm{Hu}-$ man Resources amounted to $12.8 \%$ (1.65 billion Euros up to 31.12 .2015$)$ of the total expenditure incurred in the NSRF 2007 - 2013. Of this, nearly 37\% (648 million Euros, 1092 projects) will be implemented to promote education and more than $63 \%$ (1,107 million Euros, 1560 projects) to support employment growth.

The highest funding of implemented projects was in Prešov (295.2 million Euros) and Košice (276.6 million Euros) regions, while in the Banská Bystrica (238.6 million Euros) and Nitra (228.8 million Euros) regions, which in terms of human resources are among the most problematic regions, the drawing of funding to promote human resources and social inclusion was approximately $20 \%$ lower (Fig. 1 ). 
Evaluation of regional disparities in the context of expenditure incurred by strategic priority 3 Human Resources pointed out that the non-investment projects did not contribute to mitigate regional disparities at present and the amount of implemented funds did not reflect the level of regional disparities. The benefits and impact absorption can be expected only with a certain time delay. We can expect that the implemented financial resources will contribute to a comprehensive solution for employment and social inclusion in Slovakia. The successful implementation of instruments of the programme period $2014-2020$ under the OP Human Resources is one of the assumptions for improving the situation in the field of human resources. 